\title{
Cervicovaginal and rectal colonization by group B Streptococci in Mexican women with full-term pregnancies
}

\author{
Azucena L. Cabrera-Reyes', Ma. del Carmen Martínez-García², Gerardo del C. Palacios-Saucedo, \\ Othón Rojas-Montes ${ }^{4}$, Adriana Cajero-Avelar ${ }^{5}$ and Fortino Solórzano-Santos* \\ ${ }^{1}$ Department of Pediatrics, Zone 27 General Hospital, Tlatelolco Gynecology-Obstetrics Hospital, Instituto Mexicano del Seguro Social, Mexico City; \\ ${ }^{2}$ Infectious Diseases Research Unit, Hospital Infantil de México Federico Gómez, Secretaría de Salud, Mexico City; ${ }^{3}$ Health Research Division, \\ UMAE Hospital de Especialidades No. 25, Instituto Mexicano del Seguro Social, Monterrey, N.L.; ${ }^{4}$ Infectious Diseases Medical Research Unit, \\ UMAE Hospital de Pediatría, Centro Médico Nacional SXXI, Instituto Mexicano del Seguro Social, Mexico City; ${ }^{5}$ Department of Pediatric Infectious \\ Diseases, Hospital Centenario Miguel Hidalgo, Secretaría de Salud, Aguascalientes, Ags. Mexico
}

\begin{abstract}
Background: A pregnant woman rectally or vaginally colonized by group B Streptococcus can infect her newborn. Patients and methods: Prospective, cross-sectional, analytical 24-month study in pregnant women. Women in labor with $\geq 36$ weeks of gestation were included. Pregnancy was classified as normal or high-risk. Main risk factors of the pregnant women were analyzed. Rectal and vaginal samples were obtained, placed in Todd-Hewitt broth and subsequently inoculated in 5\% sheep blood agar. Identification was carried out by biochemical tests and latex agglutination. Results: 3,347 pregnant women were included. Mean age was $25.6 \pm 5.3$ years, 95.5\% received antenatal care; 2,213 (66\%) had normal-risk pregnancies, and in 1,370 (41\%), delivery was by cesarean section. Overall colonization was $4.3 \%(145 / 3,347)$, and it was higher in the 30-34 years age group (6.8\%). Serotype I (58\%) was the most common. Conclusion: The percentage of colonization in this population was low. A routine cervicovaginal and rectal culture program in pregnant women and the intrapartum antimicrobial prophylaxis program are controversial in our region.
\end{abstract}

KEY WORDS: Cervicovaginal colonization. Group B streptococcus. Pregnancy.

\section{Colonización cervicovaginal y rectal por estreptococos del grupo B en embarazadas mexicanas a término}

\section{Resumen}

Antecedentes: Una mujer embarazada colonizada por estreptococo del grupo B por vía rectal o vaginal puede infectar a su recién nacido. Pacientes y métodos: Estudio prospectivo, transversal y analítico, durante 24 meses, en embarazadas. Se incluyeron aquellas en trabajo de parto con $\geq 36$ semanas de gestación. El embarazo se clasificó como normal o de alto riesgo. Se analizaron los principales factores de riesgo de las embarazadas. Se tomaron muestras rectales y vaginales, se colocaron en caldo Todd-Hewitt y posteriormente se inocularon en agar sangre de carnero al 5\%. La identificación se realizó mediante pruebas bioquímicas y aglutinación con látex. Resultados: Se incluyeron 3,347 embarazadas, edad media 25.6 + 5.3 años, 95.5\% con control prenatal; 2,213 (66\%) embarazo de riesgo normal y 1,370 (41\%) obtenidas por cesárea. La colonización global fue del $4.3 \%$ (145/3,347), siendo mayor en el grupo de edad de 30 a 34 años (6.8\%). El serotipo I (58\%) 
fue el más frecuente. Conclusión: El porcentaje de colonización en esta población fue bajo. Un programa sistemático de cultivo cervicovaginal y rectal en mujeres embarazadas y el programa de profilaxis antimicrobiana intraparto son controvertidos en nuestra región.

PALABRAS CLAVE: Colonización cervicovaginal. Estreptococo del grupo B. Embarazo.

Streptococcus agalactiae or group B Streptococcus (GBS) is a gram-positive coccus that frequently colonizes the lower digestive tract.

In 1938, Fry described its capacity as a human pathogen. ${ }^{1}$ Since the 1970s, there has been an increase in perinatal infections by this microorganism in developed countries, and in the 1980s, it was considered the most common cause of neonatal sepsis and meningitis. ${ }^{2-5}$ GBS is one of the main etiological agents in perinatal infections, with chorioamnionitis, spontaneous abortions and postpartum infections standing out. ${ }^{6}$

A mother with genital or rectal GBS colonization might transmit this microorganism to her newborn (NB) by hematogenous-transplacental route, by ascending route or during the passage through the cervicovaginal canal. ${ }^{7}$ In developed countries, different preemptive measures have been implemented in order to prevent vertical transmission, including intrapartum antibiotic prophylaxis. ${ }^{8,9}$ To implement these measures, it is necessary to know the frequency of maternal colonization by specific region in order for local perinatal risk to be inferred.

Most studies on GBS colonization and infection have been carried out in developed countries; in Mexico, information is limited with regard to the number of studies and evaluated regions..$^{10-15}$

In this study, the frequency of cervicovaginal and rectal colonization by GBS was determined in a sample of pregnant women cared for in a gynecology-obstetrics hospital of Mexico City.

\section{Patients and methods}

\section{Design and patients}

A 24-month observational, prospective, cross-sectional, analytical study was carried out in pregnant women. Pregnant women admitted for the care of labor were included, with those with $\geq 36$ weeks of pregnancy and those with 35-36 weeks of pregnancy on active labor and no response to labor inhibition being chosen. Those who had received antibiotics (penicillin, cephalosporin, trimethoprim-sulfamethoxazole and/or erythromycin) within the last trimester of pregnancy and those with medical contraindications (placenta previa, premature birth, placental abruption) were excluded. Pregnancies were classified as normal or high-risk according to Coopland's classification. ${ }^{16}$

\section{Sampling}

A group of trained nurses, at first examination in the delivery room or in the operating room, placed each patient in gynecological position. Wearing sterile gloves, a 15-cm plastic cotton-tipped swab was inserted in the vagina, turned, and moved laterally; the sample was placed in a tube with Todd-Hewitt (TH) broth (Becton-Dickinson) with nalidixic acid $(15 \mu \mathrm{g} / \mathrm{mL})$ and gentamicin $(8 \mu \mathrm{g} / \mathrm{mL})$. In the same position, a rectal sample was taken by inserting the swab $2 \mathrm{~cm}$ into the rectal ampulla, turning it on its own axis and placing it in another tube with $\mathrm{HT}$. The tubes remained in the delivery area at room temperature $\left(25^{\circ} \mathrm{C}\right)$ for 18 to 24 hours and were taken to the laboratory every morning.

\section{Bacterial identification}

The $\mathrm{TH}$ tubes that showed turbidity were inoculated on $5 \%$ sheep blood agar plates (SBA5\%); those that had no turbidity were incubated for $48 \mathrm{~h}$ more, and those that showed turbidity were inoculated on SBA5\%. The plates were incubated for 24 hours at $37{ }^{\circ} \mathrm{C}$, and $\beta$-hemolytic, gram-positive, catalase test-negative, hippurate hydrolysis-positive and CAMP-positive colonies were isolated. Identification of group and soluble antigens for serotypes I, II and III was carried out with a latex agglutination test (Pastorex B Streptococci ${ }^{\circledR}$, Sanofi Diagnostic Pasteur, France). In the absence of agglutination, the isolate was considered non-typeable (NT).

The study was approved by the Ethics and Research Committee of the Tlatelolco Gynecology-Obstetrics Hospital (registration no. 98-701-0010). Written informed consent was obtained from all participants.

\section{Statistical analysis}

Descriptive statistics were used for general characteristics of the sample. The chi-square test $\left(\mathrm{X}^{2}\right)$ was 
used to compare the prevalence of GBS colonization between women with normal and high-risk pregnancies. A p-value $<0.05$ was considered to be significant.

\section{Results}

Over a 24-month period, 3,347 pregnant women were included; 2,213 had a usual risk pregnancy (66\%), and 1,134, a high-risk pregnancy (34\%). Mean age was $25.6 \pm 5.3$ years (range: $14-43$ years), $95.5 \%$ had prenatal care. Cesarean section was carried out in $1,370(41 \%)$, with its use being higher in the high-risk pregnancy group (62 vs. $32 \%, p<0.001$ ). Urinary infection occurred in $27.5 \%$, and $15.5 \%$ had premature rupture of membranes (PROM), while preeclampsia was observed in $10.8 \%$ and anemia in $1.6 \%$. There were significant differences in some characteristics: age, diabetes, preeclampsia, obesity, fever and PROM $>12$ hours. The remaining characteristics are presented in table 1.

\section{Maternal colonization}

Vaginal and rectal cultures were obtained in all 3,347 pregnant women, with GBS being isolated from one or both sites in 145 , for a colonization rate of $4.3 \%$. This rate was higher in women aged between 30 and 34 years $(6.8 \%)$ with a significant difference with those younger than 19 years ( 3.6 vs. $6.8 \%, p=0.033$ ) and those younger than 25 and 30 years (Table 2). GBS was isolated only from the vagina in $85 / 145(59 \%)$, from the rectum in $36 / 145(25 \%)$, and from both sites in $24 / 145$ (17\%); this corresponds to $60 / 145$ (42\%) women rectally and 109/145 (75\%) vaginally colonized (Fig. 1). GBS colonization was higher in the high-risk pregnancy group than in the usual risk group (5.9 vs. $3.4 \%, p=0.001$ ) and in married women, with fever and a history of urinary infection. The frequency of PROM was higher in non-colonized pregnant women. There was no significant difference in any of the other evaluated characteristics (Table 3 ).

\section{Serotypes}

Serotype I (58\%) was the most common in both groups. Although higher identification of serotype III (24 vs. $21 \%$ ) and lower frequency of serotype II (9 vs. $16 \%)$ was observed in the high-risk group, there were no significant differences $(p=0.42)$ (Table 4).
Table 1. Characteristics of 3,347 pregnant women cared for in a gynecology-obstetrics hospital of Mexico City

\begin{tabular}{|c|c|c|c|}
\hline & \multicolumn{2}{|c|}{ Pregnancy risk } & \multirow[t]{2}{*}{ p } \\
\hline & Usual & High & \\
\hline $\begin{array}{l}\text { Age, years } \\
\text { (mean } \pm \text { SD) }\end{array}$ & $24.9 \pm 4.9$ & $26.9 \pm 5.7$ & $0.0001^{+}$ \\
\hline $\begin{array}{l}\text { Marital status } \\
\text { Single } \\
\text { Married }\end{array}$ & $\begin{array}{c}178(8 \%) \\
2,036(92 \%)\end{array}$ & $\begin{array}{c}57(5 \%) \\
1,076(95 \%)\end{array}$ & $0.003^{*}$ \\
\hline $\begin{array}{l}\text { Number of pregnancies } \\
\leq 2 \\
\geq 3\end{array}$ & $\begin{array}{c}1,703(76.9 \%) \\
510(23 \%)\end{array}$ & $\begin{array}{l}775(68.3 \%) \\
357(31.4 \%)\end{array}$ & $0.0001^{*}$ \\
\hline Prenatal care & $2,110(95 \%)$ & $1,085(96 \%)$ & 0.28 \\
\hline Diabetes & $1(0.04 \%)$ & $7(0.6 \%)$ & $0.003^{\star}$ \\
\hline Obesity & $317(14 \%)$ & 467 (41\%) & $0.0001^{*}$ \\
\hline Preeclampsia & $46(2 \%)$ & $316(28 \%)$ & $0.0001^{*}$ \\
\hline Fever & $3(0.1 \%)$ & $11(1 \%)$ & $0.001^{*}$ \\
\hline Urinary tract infection & $8(0.4 \%)$ & $8(0.7 \%)$ & 0.13 \\
\hline Chorioamnionitis & 0 & $4(0.4 \%)$ & $0.013^{*}$ \\
\hline $\mathrm{PROM}>12 \mathrm{~h}$ & $18(0.8 \%)$ & $60(5.3 \%)$ & $0.0001^{*}$ \\
\hline Cesarean section & $681(32 \%)$ & $689(62 \%)$ & $0.0001^{*}$ \\
\hline BGS positive culture & 77 (3.47\%) & 68 (5.99\%) & $0.001^{*}$ \\
\hline Total & $2,213(66 \%)$ & $1,134(34 \%)$ & \\
\hline
\end{tabular}

\section{*Fisher's exact test.}

'Student's t-test.

SD: standard deviation; PROM: premature rupture of membranes; GBS: group B Streptococcus.

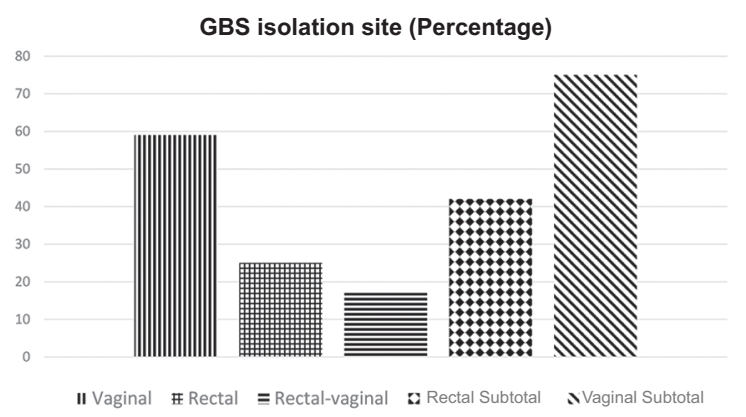

Figure 1. B-group Streptococcus (BGS) isolation site in 145 pregnant women cared for in a gynecology-obstetrics hospital of Mexico City.

\section{Discussion}

GBS is considered normal microbiota of the intestine, vagina and rectum; however, it is identified as an important pathogen of the NB and the pregnant woman. Worldwide, approximately one in every five 
Table 2. Colonization by group B Streptococcus in pregnant women from a gynecology-obstetrics hospital of Mexico City

\begin{tabular}{|l|c|c|c|}
\hline Age (years) & $\begin{array}{c}\text { Colonized } \\
\text { pregnant women }\end{array}$ & $\begin{array}{c}\text { Total pregnant } \\
\text { women }\end{array}$ & $p$ \\
\hline$\leq 19^{*}$ & $16(3.6 \%)$ & 442 & \\
\hline $20-24$ & $33(3.1 \%)$ & 1,052 & 0.64 \\
\hline $25-29$ & $51(4.7 \%)$ & 1,093 & $0.007^{\dagger}$ \\
\hline $30-34$ & $38(6.8 \%)$ & 556 & $0.033^{\ddagger}$ \\
\hline$>35$ & $7(3.4 \%)$ & 204 & $0.026^{\S}$ \\
\hline $\begin{array}{l}\text { Total } \\
\text { *First stratum was taken as reference. } \\
\text { tFisher's exact test, when < 25 years vs. }>25 \text { years are contrasted. } \\
\text { tFisher's exact test, when } 30-34 \text { vs. } \leq 19 \text { years are contrasted. } \\
\text { sFisher's exact test, when }>35 \text { years vs. < } 30 \text { years are contrasted. }\end{array}$ & \\
\hline
\end{tabular}

pregnant women is colonized, ${ }^{17}$ which is a known risk factor for early invasive neonatal disease..$^{18,19}$ The frequency of this phenomenon varies according to the colonized site, gestational age and route of delivery, as well as to intrinsic differences and geographic location of the studied populations.

There is no established international standard for maternal GBS colonization sampling, which generates variations when studies from different countries are compared. These variations may be due to the sampling method and timing, sampled anatomical sites and laboratory techniques used for sample transportation and culture..$^{20,21}$

In the present study, the frequency of colonization $(4.3 \%)$ was lower than that reported in the world (17.9\%, 95\% confidence interval [Cl]: 16.2-19.7\%), ${ }^{22}$ with a range of $11.1 \%(95 \% \mathrm{Cl}: 6.8-15.3 \%)$ in Southeast Asia to $22.4 \%$ in Africa (95\% Cl: $18.1-26.7 \%$ ). Some countries such as Brazil (14\%), China (14\%), Nigeria (19.5\%) and Saudi Arabia (19\%) have a high frequency. $22-27$ In Mexico there are also differences with previous studies: in 1981, Collado et al. found $4 \%$ of colonization; ${ }^{10}$ however, in a tertiary care center in Mexico City, $10.3 \%$ was reported; in a rural population in the south of the country, $8.6 \%$ was found, ${ }^{12}$ and in a secondary care hospital in western Mexico, $13 \% .^{13}$ Colonization in the high-risk population of the present study was lower than that found in 1989 in Mexico City (6 vs. $10.3 \%) .{ }^{11}$ Perhaps the differences in the present study could be explained by the sample size and by the fact that the sampling was carried out in pregnant women who were in labor, who had been recently admitted, with the majority of them having full-term pregnancies. GBS colonization was higher in women with high-risk pregnancy, with frequency increasing at
Table 3. Characteristics of pregnant women colonized and not colonized by group B Streptococcus (GBS)

\begin{tabular}{|c|c|c|c|}
\hline & \multicolumn{2}{|c|}{ GBS culture } & \multirow[t]{2}{*}{$\mathrm{p}$} \\
\hline & $\begin{array}{c}\text { Positive } \\
\text { n (\%) }\end{array}$ & $\begin{array}{c}\text { Negative } \\
\text { n (\%) }\end{array}$ & \\
\hline $\begin{array}{l}\text { Age, years } \\
(\text { Mean } \pm \text { SD) }\end{array}$ & $26.6 \pm 5$ & $25.5 \pm 5.2$ & $0.01^{*}$ \\
\hline $\begin{array}{l}\text { Marital status } \\
\text { Single } \\
\text { Married } \\
\text { Unknown }\end{array}$ & $\begin{array}{c}5(3.4 \%) \\
138(95.1 \%) \\
2(1.4 \%)\end{array}$ & $\begin{array}{c}232(7.2 \%) \\
2,920(91.2 \%) \\
50(1.5 \%)\end{array}$ & $0.047^{\dagger}$ \\
\hline $\begin{array}{l}\text { Number of pregnancies } \\
<3 \\
\geq 3\end{array}$ & $\begin{array}{l}105(72.4 \%) \\
40(27.6 \%)\end{array}$ & $\begin{array}{c}2,374(74.1 \%) \\
828(25.9 \%)\end{array}$ & $0.35^{\dagger}$ \\
\hline $\begin{array}{l}\text { Gestational age, weeks } \\
\leq 36 \\
\geq 37\end{array}$ & $\begin{array}{c}2(1.3 \%) \\
143(98.6 \%)\end{array}$ & $\begin{array}{c}132(4.1 \%) \\
3,070(95.9 \%)\end{array}$ & $0.06^{\ddagger}$ \\
\hline Obesity & $40(28 \%)$ & $745(23 \%)$ & $0.13^{+}$ \\
\hline Diabetes & 0 & $8(0.2 \%)$ & $0.7^{\dagger}$ \\
\hline PROM & $15(10.3 \%)$ & $505(16 \%)$ & $0.04^{\dagger}$ \\
\hline Preeclampsia & $16(11 \%)$ & $346(11 \%)$ & $0.50^{+}$ \\
\hline Fever & $2(1.3 \%)$ & $11(0.3 \%)$ & $0.02^{\dagger}$ \\
\hline Recent urinary infection & $2(1.3 \%)$ & $14(0.4 \%)$ & $0.15^{\dagger}$ \\
\hline Past urinary infection & $50(34.4 \%)$ & $870(27 \%)$ & $0.03^{\dagger}$ \\
\hline Chorioamnionitis & $1(0.7 \%)$ & $3(0.1 \%)$ & $0.16^{\dagger}$ \\
\hline Total & $145(100 \%)$ & $3,202(100 \%)$ & \\
\hline
\end{tabular}

Table 4. Group B Streptococcus (GBS) serotypes in women with usual and high-risk pregnancy

\begin{tabular}{|l|c|c|c|}
\hline \multirow{2}{*}{ Serotype } & \multicolumn{2}{|c|}{ Pregnancy risk } & \multirow{2}{*}{ Total } \\
\cline { 2 - 3 } & $\begin{array}{l}\text { Usual } \\
n(\%)\end{array}$ & $\begin{array}{l}\text { High } \\
n(\%)\end{array}$ & \\
\hline I & $42(55 \%)$ & $42(62 \%)$ & $84(58 \%)$ \\
\hline II & $12(16 \%)$ & $6(9 \%)$ & $18(13 \%)$ \\
\hline III & $16(21 \%)$ & $17(25 \%)$ & $33(22 \%)$ \\
\hline NT & $7(9 \%)$ & $3(5 \%)$ & $10(7 \%)$ \\
\hline $\begin{array}{l}\text { GBS positive } \\
\text { culture }\end{array}$ & $77(100)$ & $68(100)$ & 145 \\
\hline
\end{tabular}

older age; however, this frequency is lower than that observed in other populations of the world. ${ }^{22-27}$ 
It has been suggested that vaginal and rectal cultures should be carried out simultaneously; in this study, $25 \%$ of isolates were obtained only from the rectum; therefore, if only vaginal cultures would had been taken, a significant percentage of colonized women would have been missed. This supports sampling at both sites. ${ }^{28}$

Worldwide, five GBS serotypes (la, Ib, II, III and V) represent $98 \%$ of predominant serotypes. ${ }^{17}$ In our study, serotype I predominated, as previously reported in Mexico ${ }^{11-14}$ and in other regions of the world. ${ }^{17}$ Serotype $\mathrm{V}$ was not searched in this study because it was considered of very low frequency in Mexico according to previous studies. ${ }^{11-14}$

Given the frequency of colonization and perinatal infections by GBS, in the United States and other developed countries, systematically searching for it is recommended in all pregnant women at between 35 and 37 weeks of gestation, and administering antibiotic prophylaxis to colonized women since four hours before delivery. This strategy has achieved a drastic decrease in the incidence of early-onset neonatal disease, without the incidence of late-onset infections being modified. ${ }^{29}$ In other countries, this policy has not been adopted due to the lack of information on colonization and transmission to the NB. In underdeveloped countries there are limitations for having epidemiological data available due to the lack of easy, rapid and low-cost tests. The performance of cultures is an expensive and time-consuming practice. Screening based on maternal risk has not offered good results. ${ }^{28}$

In the population of Mexican women, cervicovaginal and rectal colonization by GBS is low in comparison with other countries; therefore, the performance of cultures in all pregnant women appears not to be justified in Mexico, considering the high cost of this practice and the low probability of detecting colonized women. For now, available information is insufficient for establishing an intrapartum antimicrobial prophylaxis program.

One weakness of this study is that only pregnant women from Mexico City were included; however, available information from other states of the country suggests that this low colonization percentage is real. ${ }^{12,13}$ The factors that may be determining this low colonization rate in the Mexican population are still unknown and, therefore, constitute a field that requires future research.

\section{Funding}

This study received funding from Instituto Mexicano del Seguro Social participating institutions.

\section{Conflict of interests}

The authors declare that they have no conflicts of interest.

\section{Ethical disclosures}

Protection of human and animal subjects. The authors declare that the procedures that were followed adhered to the ethical standards of the responsible committee for experimentation on human beings and were in agreement with the World Medical Association and the Declaration of Helsinki.

Confidentiality of data. The authors declare that they have followed the protocols of their work center on the publication of patient data.

Right to privacy and informed consent. The authors declare that no patient data appear in this article.

\section{References}

1. Fry RM. Fatal infections by hemolytic streptococcus group B. Lancet. 1938:1:199-201.

2. Eickhoff TC, Klein JO, Daly KA, Ingall D, Finland M. Neonatal sepsis and other infections due to group B beta-hemolytic Streptococci. N Engl J Med. 1964;271:1221-8.

3. Stoll BJ, Gordon T, Korones SB, Shankaran S, Tyson JE, Bauer CR. Early-onset sepsis in very low birth weight neonates: A report from the National Institute of Child Health and Human Development Neonatal Research Network. J Pediatr. 1996;129:73-80.

4. Baltimore RS, Huie SM, Meek JI, Schuchat A, O'Brien KL. Early-onset neonatal sepsis in the era of group B Streptococcal prevention. Pediatrics 2001;108:1094-8.

5. Kalliola S, Vuopio-Varkila J, Takala AK, Eskola J. Neonatal group B streptococcal disease in Finland: a ten-year nationwide study. Pediatr Infect Dis J. 1999;18(9):806-10.

6. Patel K, Williams S, Guirguis G, Gittens-Williams L, Apuzzio J. Genita tract GBS and rate of histologic chorioamnionitis in patients with PPROM. J Matern Fetal Neonatal Med. 2018;31(19):2624-7.

7. Edmond KM, Kortsalioudaki C, Scott S, Schrag SJ, Zaidi AKM, Cousens S, et al. Group B streptococcal disease in infants aged younger than 3 months: systematic review and meta-analysis. Lancet. 2012;379:547-56.

8. Alhhazmi A, Hurteau D, Tyrrell GJ. Epidemiology of invasive group B streptococcal disease in Alberta, Canada, from 2003 to 2013. J Clin Microbiol. 2016;54(7):1774-81.

9. O'Sullivan CP, Lamagni T, Patel D, Efstratiou A, Cunney R, Meehan M, et al. Group B streptococcal disease in UK and Irish infants younger than 90 days, 2014-15: a prospective surveillance study. Lancet Infect Dis. 2019;19(1):83-90.

10. Collado M, Kretschmer RR, Becker I, Guzmán A, Gallardo L, Lepe CM. Colonization of Mexican pregnant women with group B streptococcus. $\mathrm{J}$ Infect Dis. 1981;143(1):134.

11. Solórzano-Santos F, Echaniz-Avilés G, Conde-Glez CJ, Calderón-Jaimes E, Arredondo-García JL, Beltrán-Zúniga M. Cervicovaginal infection with group B streptococci among pregnant Mexican women. J Infect Dis. 1989;159(5):1003-4

12. Ocampo-Torres M, Sánchez-Pérez HJ, Nazar-Beutelspacher A, Castro-Ramírez AE, Cordero-Ocampo B. Factors associated with Streptococcus group $B$ colonization in pregnant women in Los Altos, Chiapas. Salud Pública Mex. 2000;42(5):413-21. 
13. Villaseñor-Sierra A, Morales-Velázquez P, Palacios-Saucedo G, Solórzano-Santos F. Prevalence of Streptococcus algalactiae serotype III in pregnant women. Ginecol Obstet Mex. 2004;72:103-8.

14. Palacios GC, González MN, Beltrán M, Arredondo JL, Torres J, Solórzano F. Serotypes of 286 group B streptococci isolated from asymptomatic carriers and invasive disease cases in Mexico. Rev Latinoam Microbiol. 2005;47(1-2):21-4.

15. Reyna-Figueroa J, Ortiz-lbarra FJ, Esteves-Jaramillo A Casanova-Román G. Maternal B group Streptococcus colonization in Mexico: prevalence based on literature review. Ginecol Obstet Mex. 2007;75(7):399-403

16. Coopland AT, Peddle LJ, Baskett TF, Rollwagen R, Simpson A, Parker E. A simplified antepartum high-risk pregnancy scoring form: statistical analysis of 5459 cases. Can Med Assoc J. 1977;116:999-1001.

17. Russell N, Seale AC, O'Driscoll M, O'Sullivan C, Bianchi-Jassir F, González-Guarín J, et al. Maternal colonization with group B Streptococcus and serotype distribution worldwide: systematic review and meta-analyses. Clin Infect Dis. 2017;65(suppl 2):S100-111.

18. Dillon HC, Santosh K, Gray BM. Group B streptococcal carriage and disease: a 6-year prospective study. J Pediatr. 1987;110:31-6.

19. Alkalay AL, Brunell PA, Greenspon JS, Pomerance JJ. Management of neonates born to mothers with group B Streptococcus colonization. J Perinatol. 1996;16:470-7.

20. Valkenburg-van den Berg AW, Houtman-Roelofsen RL, Oostvogel PM, Dekker FW, Dörr PJ, Sprij AJ. Timing of group B Streptococcus screening in pregnancy: a systematic review. Gynecol Obstet Invest. 2010;69:174-83.
21. Badri MS, Zawaneh S, Cruz AC, Mantilla G, Baer H, Spellacy WN, et al. Rectal colonization with group B Streptococcus: relation to vaginal colonization of pregnant women. J Infect Dis. 1977;135:308-12.

22. Kwatra G, Cunnington MC, Merrall E, Adrian PV, Ip M, Klugman KP, et al. Prevalence of maternal colonization with group B Streptococcus: a systematic review and meta-analysis. Lancet Infect Dis. 2016;16:1076-84.

23. Hickman ME, Rench MA, Ferrieri P, Baker CJ. Changing epidemiology of group B streptococcal colonization. Pediatrics. 1999;104:203-9.

24. Zhu Y, Huang J, Lin XZ, Chen C. Group B Streptococcus colonization in late pregnancy and invasive infection in neonates in China: A population-based 3-year study. Neonatology. 2019;115(4):301-9.

25. Musleh J, Al Qahtani N. Group B Streptococcus colonization among Saudi women during labor. Saudi J Med Med Sci. 2018;6(1):18-22.

26. Siqueira F, Ferreira EM, de Matos Calderon I, Dias A. Prevalence of colonization by group $B$ streptococcus in pregnant patients in Taguatinga, Federal District, Brazil: a cross-sectional study. Arch Gynecol Obstet. 2019;299(3):703-11.

27. Gizachew M, Tiruneh M, Moges F, Tessema B. Streptococcus agalactiae maternal colonization, antibiotic resistance and serotype profiles in Africa: a meta-analysis. Ann Clin Microbiol Antimicrob. 2019;18(1):14.

28. Khalil MR, Uldbjerg N, Thorsen PB, Møller JK. Risk-based approach versus culture-based screening for identification of group $B$ streptococci among women in labor. Int J Gynaecol Obstet. 2019;144(2):187-91.

29. Schrag SJ, Verani JR. Intrapartum antibiotic prophylaxis for the prevention of perinatal group B streptococcal disease: experience in the United States and implications for a potential group B streptococcal vaccine. Vaccine. 2013;31(Suppl 4):D20-6. 